\title{
A case of failed eradication of cystic fibrosis-related sinus colonisation by Pseudomonas aeruginosa
}

\author{
Barry Linnane ${ }^{1,2,3}$, Linda Kearse ${ }^{1,3}$, Nuala H. O' Connell ${ }^{1,2}$, John Fenton ${ }^{1,2}$, Miranda G. Kiernan ${ }^{1}$ \\ and Colum P. Dunne ${ }^{1 *}$
}

\begin{abstract}
Background: Pseudomonas aeruginosa is a pathogen associated with cystic fibrosis that has potential to decrease lung function and cause respiratory failure. Paranasal sinuses are increasingly recognised as potential reservoirs for intermittent colonisation by $P$. aeruginosa. This case documents investigation and outcome of $P$. aeruginosa recurrence in a male paediatric patient over an eight year period.

Case presentation: A 12 year old Irish male paediatric cystic fibrosis patient experienced intermittent culturing of P. aeruginosa from the oropharyngeal region, indicating chronic infection of the sinuses despite absence of symptoms, retaining good lung function, and normal bronchoscopy and bronchoalveloar lavage. However, P. aeruginosa was isolated from a sinus wash-out and was identified as a unique strain of $P$. aeruginosa that was also cultured from cough swabs. Despite treatment, successful eradication from the paranasal sinuses was not achieved.

Conclusions: Few reports have addressed the paranasal sinuses as a reservoir for lung infection in cystic fibrosis patients despite increased recognition of the need to investigate this niche. In this case, attempts at eradication of $P$. aeruginosa present in paranasal sinuses including oral and nebulised antimicrobials proved unsuccessful. However, detection of P. aeruginosa in the paranasal sinuses instigated antimicrobial treatment which may have contributed to prevention of migration to the lower airways. Our outcome provides additional insight and may indicate utility of nasal lavage or nasal endoscopy in paediatric cystic fibrosis patients' annual review clinic visits.
\end{abstract}

Keywords: Cystic fibrosis, Pseudomonas aeruginosa, Paranasal sinuses, Eradication regimen

\section{Background}

The Cystic Fibrosis (CF) patient airway is defective in ciliary function; resulting, due to ineffective removal, in a mucus-rich environment [1] favouring growth of bacteria [2], including potential pathogens, such as, but not limited to, Staphylococcus aureus, Haemophilus influenza and Pseudomonas aeruginosa [1] associated with chronic infection [3], decreased lung function [4] and accelerated respiratory disease [5]. Consequently, risk of mortality for paediatric CF patients with lower airway infection by $P$. aeruginosa has been reported as almost three times higher than for those without [5].

\footnotetext{
* Correspondence: colum.dunne@ul.ie

${ }^{1}$ Graduate Entry Medical School and Centre for Interventions in Infection, Inflammation \& Immunity (4i), University of Limerick, Limerick, Ireland Full list of author information is available at the end of the article
}

There has been limited study of the paranasal sinuses as reservoirs for $P$. aeruginosa [6-11]. However, it is believed that due to poor mucociliary clearance in the paranasal sinuses and the lower airways, and physiological similarities between the membranes of the sinuses and the conductive bronchi, that $P$. aeruginosa migration from the sinuses to the lower airways may occur $[6,12]$. Chronic $P$. aeruginosa infection is often preceded by a period of intermittent colonisation of the airways $[8,13]$, sometimes in the absence of symptoms of infection or immunological responses [14]. Adding additional complexity, in the context of managing CF patients successfully, the colonising $P$. aeruginosa may undergo substantial genetic adaptation and diversification into subpopulations with varying phenotypic traits (including nutient utilisation, growth rates, exopolysaccharide production and antimicrobial resistances) 
and, with regard to microbiological analysis, differing colony morphologies $[1,8,15,16]$.

The paranasal sinuses may become a focus for regular examination or antimicrobial treatment in CF patients, such as functional endoscopic sinus surgery promoted by Danish clincians [13, 17]. Similarly, the oral cavity has been identified as a potential reservoir for pathogenic bacteria in CF patients [18, 19], with failure to determine presence of pathogens potentially detrimental to CF patients. In this case, we focus on and describe intermittent $P$. aeruginosa colonisation of the oropharyngeal region of a paediatric patient and, supporting the rationale of the Danish group, the role of the paranasal sinuses specifically as reservoirs that contributed to our failure to eradicate the pathogen despite successive antimicrobial administration.

\section{Case presentation}

Ethical approval and informed consent for this study was approved by the HSE Mid-Western Regional Hospital Research Ethics Committee. A 12 year old asymptomatic patient (homozygous for Phe508del) with good lung function (mean forced expiratory volume - $\mathrm{FEV}_{1}$ ) from March 2009 to June 2014: $91.6 \% \pm 1.46 \%$ ) and normal bronchoscopy with no bacterial growth from two bronchoalveloar lavages (BAL) (considered the 'gold standard' method for collection of samples from the lower airways [20,21]), displayed intermittent chronic $P$. aeruginosa infection of the oropharyngeal region (or at least detection using the oropharyngeal swab) between September 2006 to September 2014. This caused the patient's parents to persistently submit elevated numbers of cough swabs for microbiological investigation. Eradication regimens comprised nebulised (via both mouth and nose) and oral antimicrobials, which appeared to clear the oropharyngeal region of $P$. aeruginosa, albeit transiently, but ultimately proved ineffective.

P. aeruginosa was first isolated in August 2006 from a cough swab, when the patient was four years of age and, thereafter, isolated once each year for three subsequent years. Microbiological assessment was in accordance with Health Protection Agency Standard Operating Procedure (HPA SOP) 57 guidelines. On each occasion that $P$. aeruginosa was identified, the patient underwent eradication regimens until three follow up monthly cough swabs were negative for growth. Samples obtained from the patient remained clear of $P$. aeruginosa from September 2008 until May 2010, when the annual recurrence pattern was re-established for three subsequent years. In December 2010 , the detection of $P$. aeruginosa resulted in administration of ciprofloxacin (oral $-500 \mathrm{mg}$ ) and tobramycin (nebulised $-300 \mathrm{mg}$ ), both b.i.d. for 28 days. However, the frequency of $P$. aeruginosa colonisation increased from March 2013, evident approximately every three months until January 2014. Although the patient never exhibited symptoms of sinusitis, and although no general anaesthesia and involvement of an ear, nose and throat (ENT) surgeon (JF) was necessary, nevertheless, a bilateral antral washout was performed in Dec 2012 and Sept 2014 as the patient was unable to expectorate and the concept of the paranasal sinuses acting as a reservoir for $P$. aeruginosa was considered.

$P$. aeruginosa was isolated from the right antral washing; therefore, the patient underwent the same eradication regimen as before, supplemented by maintenance therapy of tobramycin (300 mg per $5 \mathrm{~mL}$ nebulised solution) and colistin (2 M IU) administered via a face mask that allowed the antimicrobials to pass through the nasal cavity. The patient was encouraged to breathe predominantly through the nose during the nebulisation sessions to ensure maximum administration to the nasal cavity. Following this extended treatment, between February and September 2014 cough swabs remained $P$. aeruginosa-free. In September 2014, the patient underwent repeat antral sinus washing, bronchoscopy and cough swab collection. P. aeruginosa was again isolated from the right antral washing. The lower airways remained clear of Pseudomonas.

$P$. aeruginosa isolates underwent molecular (Variable Number Tandem Repeat) and phenotypic characterisation (Table 1). Antimicrobial sensitivity profiles were generated for each isolate (from August 2006 until September 2014) based on CLSI and EUCAST guidelines [22, 23] (Table 2). VNTR analysis demonstrated that all isolates represented the same unique $P$. aeruginosa strain. Phenotypic analysis classified all except two isolates (September 2013 and 2014) as mucoid, a characteristic not seen in the majority (6 out of 7) of isolates previously. Isolates were proteolytic and siderophore producing (Table 1). All isolates were susceptible to tobramycin, ciprofloxacin and meropenem, while the majority (all but antral washing Sept 2014) were also susceptible to pipercillin/tazobactum (Table 2).

\section{Conclusions}

Our findings demonstrate that the paranasal sinuses acted as protected reservoirs for $P$. aeruginosa as verified by VNTR profiling, supporting previous (albeit few) reports $[13,17]$. As with other researchers $[16,24,25]$, we found indications of adaptation of the $P$. aeruginosa strain, whereby prior to March 2013, all but one P. aeruginosa isolate from our patient were classified (based on colony morphology) as non-mucoid, whereas on and after this date, four of six isolates were phenotypically mucoid (Table 1). Such mucoidy is due to an overproduction of polysaccharide alginate, which contributes to biofilm formation [26] and increased resistance to antimicrobials [27]. It is believed that a non-mucoid phenotype is most often associated with isolates from early infection while mucoid strains are more frequently associated 
Table 1 Phenotypic profile of Pseudomonas aeruginosa isolates from a paediatric patient over $\mathrm{n} 8$ year period

\begin{tabular}{|c|c|c|c|c|c|}
\hline \multirow[b]{2}{*}{ Date specimen taken } & \multirow[b]{2}{*}{ Specimen cultured from (Location) } & \multicolumn{4}{|l|}{ Phenotypic classification } \\
\hline & & Gram staining + ve or -ve & Mucoid (+ or - ) & $\begin{array}{l}\text { Proteolytic } \\
(+/++/+++)\end{array}$ & $\begin{array}{l}\text { Siderophore producing } \\
(+/++/+++)\end{array}$ \\
\hline $11 / 08 / 06^{\mathrm{a}}$ & Cough Swab & - & - & & \\
\hline $23 / 08 / 07^{c}$ & Cough Swab & - & - & & \\
\hline $07 / 08 / 08^{c, d}$ & Cough Swab & - & - & & \\
\hline 05/05/10 & Cough Swab & - & - & & \\
\hline $14 / 12 / 10$ & Cough Swab & - & + & & \\
\hline $22 / 04 / 11^{b}$ & Cough Swab & - & - & & \\
\hline $10 / 04 / 12^{b, c, d}$ & Cough Swab & - & - & & \\
\hline $23 / 03 / 13$ & Cough Swab & - & + & +++ & +++ \\
\hline $06 / 06 / 13^{c}$ & Cough Swab & - & + & ++ & + \\
\hline $30 / 09 / 13$ & Cough Swab & - & - & +++ & ++ \\
\hline 20/12/13 & Cough Swab & - & + & + & + \\
\hline $23 / 01 / 14^{e}$ & Antral Washing & - & + & ++ & +++ \\
\hline $11 / 09 / 14$ & Antral Washing & - & - & + & + \\
\hline
\end{tabular}

${ }^{\mathrm{a} F i r s t}$ identification of Pseudomonas aeruginosa. ${ }^{\mathrm{b}} \mathrm{P}$. aeruginosa growth described as "scanty" by University Hospital Limerick microbiology laboratory. 'Staphylococcus aureus also identified in addition to P. aeruginosa

${ }^{\mathrm{d}}$ Haemophilus parainfluenzae also identified in addition to P. aeruginosa. ${ }^{\mathrm{e}}$ Pseudomonas fluorescens also identified in addition to $P$. aeruginosa Where $+=$ low,$++=$ intermediate, $+++=$ high

with established infection [3] and, indeed, poorer patient prognosis [28]. In our study, the same isolates were identified as proteolytic (associated with damage to tissue [29]) and siderophore producing (linked to bacterial virulence $[30,31]$ ) producing (Table 1), although no pattern of changing protease or siderophore activity was discernible.

Antimicrobials are used commonly in treatment of initial colonisation of $P$. aeruginosa to postpone chronic infection and respiratory dysfunction, often delivered orally (e.g., ciprofloxacin) or nebulised (e.g., tobramycin) [13, 32, 33]. In this case, analogous to the approach adopted successfully elsewhere [34, 35], additional maintenance therapy comprised nebulised tobramycin and colomycin on alternate months, for six months. However, in our case, this ultimately proved unsuccessful. Other groups have recognised the challenge of eradicating $P$. aeruginosa from the paranasal sinuses using existing approaches and have have begun

Table 2 Antimicrobial sensitivity profile for Pseudomonas aeruginosa from a paediatric patient over an 8 year period

\begin{tabular}{|c|c|c|c|c|c|c|c|c|c|c|c|c|c|c|c|c|}
\hline & \multicolumn{8}{|l|}{ CLSI Guidelines } & \multicolumn{8}{|l|}{ EUCAST Guidelines } \\
\hline & \multirow[t]{2}{*}{ Disk content $(\mu \mathrm{g})$} & \multirow{2}{*}{$\begin{array}{l}2006 \\
11 / 8\end{array}$} & \multirow{2}{*}{$\begin{array}{l}2007 \\
23 / 8\end{array}$} & \multirow{2}{*}{$\begin{array}{l}2008 \\
6 / 8\end{array}$} & \multicolumn{2}{|c|}{2010} & \multirow{2}{*}{$\begin{array}{l}2011 \\
22 / 4\end{array}$} & \multirow{2}{*}{$\begin{array}{l}2012 \\
10 / 4\end{array}$} & \multirow[t]{2}{*}{ Disk content $(\mu \mathrm{g})$} & \multicolumn{4}{|l|}{2013} & \multicolumn{3}{|l|}{2014} \\
\hline & & & & & $5 / 5$ & $14 / 12$ & & & & $26 / 3$ & $6 / 6$ & $30 / 9$ & $20 / 12$ & $23 / 1$ & $23 / 1^{\mathrm{a}}$ & $11 / 9^{\mathrm{a}}$ \\
\hline \multicolumn{17}{|l|}{ Drug } \\
\hline Ofloxacin & 5 & $S$ & $S$ & NT & NT & NT & NT & NT & 0 & NT & NT & NT & NT & NT & NT & NT \\
\hline $\begin{array}{l}\text { Pipercillin/ } \\
\text { Tazobactum }\end{array}$ & $100 / 10$ & $S$ & $S$ & $S$ & $S$ & $S$ & $S$ & $S$ & 36 & $S$ & S & $S$ & S & $S$ & $\mathrm{R}$ & S \\
\hline Ceftazidime & 30 & $S$ & $S$ & $S$ & $\mathrm{~s}$ & $S$ & $S$ & $\mathrm{~S}$ & 10 & $\mathrm{~S}$ & $S$ & $S$ & S & $S$ & $\mathrm{~S}$ & $\mathrm{~S}$ \\
\hline Tobramycin & 10 & $S$ & $S$ & S & $S$ & $S$ & $S$ & $S$ & 10 & $S$ & S & $S$ & S & $S$ & S & 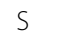 \\
\hline Ciprofloxacin & 5 & NT & $S$ & NT & $\mathrm{S}$ & $S$ & $S$ & S & 5 & $S$ & $S$ & $S$ & $\mathrm{~S}$ & $\mathrm{~S}$ & S & $\mathrm{S}$ \\
\hline Amikacin & 30 & NT & $S$ & NT & NT & NT & NT & NT & 30 & NT & NT & NT & NT & NT & NT & NT \\
\hline Aztreoman & 30 & NT & S & NT & NT & NT & NT & $\mathrm{S}$ & 30 & $S$ & । & I & I & I & । & । \\
\hline Colistin (E-Test) & 10 & NT & $S$ & NT & NT & NT & NT & NT & 10 & NT & NT & S & $\mathrm{S}$ & $\mathrm{S}$ & $\mathrm{S}$ & $\mathrm{S}$ \\
\hline Imipenem & 10 & NT & $S$ & NT & NT & NT & NT & NT & 10 & NT & NT & NT & NT & NT & NT & NT \\
\hline Meropenem & 10 & NT & $S$ & $S$ & $\mathrm{~S}$ & S & S & $\mathrm{S}$ & 10 & $S$ & $\mathrm{~S}$ & $S$ & $\mathrm{~S}$ & $\mathrm{~S}$ & $\mathrm{~S}$ & $\mathrm{~S}$ \\
\hline
\end{tabular}

$S$ Susceptible, I Intermediate, $R$ Resistant and NT Not Tested

${ }^{\text {a }} P$. aeruginosa isolated from antral washing 
to evaluate novel strategies such as inhalation of tobramycin using vibrating [36] or pulsating [37] aerosols or addition of hyaluronate to nasal sprays [38].

In our case, although the eradication regimen proved unsuccessful in decolonising the paranasal sinuses of $P$. aeruginosa, we believe that detection of the pathogen instigated antimicrobial treatment that may have contributed to prevention of migration to the lower airways and, therefore, preventing chronic infection of the lower airways. Our case supports the rationale for assessment of the paranasal sinuses as potential $P$. aeruginosa reservoirs in CF patients displaying intermittent colonisation patterns albeit that the currently available techniques are invasive, require general anaesthesia and prudent antimicrobial use as they may themselves, due to physical disruption, cause migration of bacteria to other airways.

\section{Consent}

Written informed consent was obtained from the patient and his parents for publication of this case report. A copy of the written consent is available for review by the Editor of this journal.

\section{Abbreviations \\ CF: Cystic fibrosis; FEV: Forced expiratory volume; BAL: Bronchoalveolar lavage; HPA: Health Protection Agency; SOP: Standard operating procedure; ENT: Ear, nose, throat; CLSI: Clinical and Laboratory Standards Institute; EUCAST: European Committee on Antimicrobial Susceptibility Testing; VNTR: Variable number tandem repeat.}

\section{Competing interests}

The authors declare that they have no competing interests.

\section{Authors' contributions}

$\mathrm{BL}, \mathrm{NO}^{\prime} \mathrm{C}$ and JF were responsible for treatment of the patient. BL, NO'C and $C D$ recognized the novelty of the Case and drafted the manuscript. LK and MK completed the microbiology analyses and drafted the manuscript. All authors read and approved the final manuscript.

\section{Authors' information}

Not applicable.

\section{Availability of data and materials}

Not applicable.

\section{Acknowledgements}

The authors acknowledge staff in the microbiology and CF units at UHL, in particular James Powell. The authors are grateful for funding provided by the Irish National Children's Research Centre (NCRC), Our Lady's Children's Hospital, Crumlin, Dublin, Ireland.

\section{Funding}

Funding to support this project was received by authors $C D, B L$ and $L K$ and was granted by the National Children's Research Centre, Crumlin, Dublin, Ireland and the University of Limerick, Graduate Entry Medical School Strategic Research Fund.

\section{Author details}

${ }^{1}$ Graduate Entry Medical School and Centre for Interventions in Infection, Inflammation \& Immunity (4i), University of Limerick, Limerick, Ireland. ${ }^{2}$ University Hospital Limerick, Dooradoyle, Limerick, Ireland. ${ }^{3}$ National Children's Research Centre (NCRC), SHIELD CF, Our Lady's Children's Hospital, Crumlin, Dublin, Ireland.
Received: 11 May 2015 Accepted: 28 September 2015

Published online: 06 October 2015

\section{References}

1. Folkesson A, Jelsbak L, Yang L, Johansen HK, Ciofu O, Hoiby N, et al. Adaptation of Pseudomonas aeruginosa to the cystic fibrosis airway: an evolutionary perspective. Nat Rev Microbiol. 2012;10(12):841-51. http://dx.doi.org/10.1038/nrmicro2907.

2. Koch C. Early infection and progression of cystic fibrosis lung disease. Pediatr Pulmonol. 2002;34(3):232-6. http://dx.doi.org/10.1002/ppul.10135.

3. Burns JL, Gibson RL, McNamara S, Yim D, Emerson J, Rosenfeld M, et al. Longitudinal assessment of Pseudomonas aeruginosa in young children with cystic fibrosis. J Infect Dis. 2001;183(3):444-52. http://dx.doi.org/10.1086/318075.

4. Navarro J, Rainisio M, Harms H, Hodson M, Koch C, Mastella G, et al. Factors associated with poor pulmonary function: cross-sectional analysis of data from the ERCF. Eur Respir J. 2001;18(2):298-305. http://dx.doi.org/10.1183/09031936.01.00068901.

5. Emerson J, Rosenfeld M, McNamara S, Ramsey B, Gibson RL. Pseudomonas aeruginosa and other predictors of mortality and morbidity in young children with cystic fibrosis. Pediatr Pulmonol. 2002;34(2):91-100. http://dx.doi.org/10.1002/ppul.10127.

6. Hansen SK, Rau MH, Johansen HK, Ciofu O, Jelsbak L, Yang L, et al. Evolution and diversification of Pseudomonas aeruginosa in the paranasal sinuses of cystic fibrosis children have implications for chronic lung infection. ISME J. 2011;6(1):31-45. http://dx.doi.org/10.1038/ismej.2011.83.

7. Mainz JG, Naehrlich L, Schien M, Käding M, Schiller I, Mayr S, et al. Concordant genotype of upper and lower airways $P$ aeruginosa and $\mathrm{S}$ aureus isolates in cystic fibrosis. Thorax. 2009;64(6):535-40 http://dx.doi.org/10.1136/thx.2008.104711.

8. Jelsbak L, Johansen HK, Frost A-L, Thøgersen R, Thomsen LE, Ciofu O, et al. Molecular epidemiology and dynamics of Pseudomonas aeruginosa populations in lungs of cystic fibrosis patients. Infect Immun. 2007;75(5):2214-24. http://dx.doi.org/10.1128/IAl.01282-06.

9. Muhlebach MS, Miller MB, Moore C, Wedd JP, Drake AF, Leigh MW. Are lower airway or throat cultures predictive of sinus bacteriology in cystic fibrosis? Pediatr Pulmonol. 2006:41(5):445-51. doi:10.1002/ppul.20396.

10. Dosanjh A, Lakhani S, Elashoff D, Chin C, Hsu V, Hilman B. A comparison of microbiologic flora of the sinuses and airway among cystic fibrosis patients with maxillary antrostomies. Pediatr Transplant. 2000;4(3):182-5.

11. Taylor CJ, McGaw J, Howden R, Duerden BI, Baxter PS. Bacterial reservoirs in cystic fibrosis. Arch Dis Child. 1990;65(2):175-7.

12. Aanaes K, Rickelt LF, Johansen HK, von Buchwald C, Pressler T, Høiby N, et al. Decreased mucosal oxygen tension in the maxillary sinuses in patients with cystic fibrosis. J Cyst Fibros. 2011;10(2):114-20 http://dx.doi.org/10.1016/j.jff.2010.12.002.

13. Hoiby N, Frederiksen B, Pressler T. Eradication of early Pseudomonas aeruginosa infection. J Cyst Fibros. 2005;4(2):49-54. http://dx.doi.org/ 10.1016/j.jff.2005.05.018.

14. Canton R, Cobos N, de Gracia J, Baquero F, Honorato J, Gartner S, et al. Antimicrobial therapy for pulmonary pathogenic colonisation and infection by Pseudomonas aeruginosa in cystic fibrosis patients. Clin Microbiol Infect. 2005;11(9):690-703. http://dx.doi.org/10.1111/j.1469-0691.2005.01217.x.

15. Yang L, Jelsbak L, Marvig RL, Damkiaer S, Workman CT, Rau MH, et al. Evolutionary dynamics of bacteria in a human host environment. Proc Natl Acad Sci U S A. 2011;108(18):7481-6. doi:10.1073/pnas.1018249108.

16. Hoffman LR, Richardson AR, Houston LS, Kulasekara HD, Martens-Habbena W, Klausen M, et al. Nutrient availability as a mechanism for selection of antibiotic tolerant Pseudomonas aeruginosa within the CF airway. PLoS Pathog. 2010;6(1):e1000712. doi:10.1371/journal.ppat.1000712.

17. Aanæs K. Bacterial sinusitis can be a focus for initial lung colonisation and chronic lung infection in patients with cystic fibrosis. J Cyst Fibros. 2013;12(2):S1-20. http://dx.doi.org/10.1016/S1569-1993(13)00150-1.

18. Lindemann RA, Newman MG, Kaufman AK, Le TV. Oral colonization and susceptibility testing of Pseudomonas aeruginosa oral isolates from cystic fibrosis patients. J Dent Res. 1985;64(1):54-7.

19. Rivas Caldas R, Le Gall F, Revert K, Rault G, Virmaux M, Gouriou S, et al. Pseudomonas aeruginosa and Periodontal Pathogens in the Oral Cavity and Lungs of Cystic Fibrosis Patients: a Case-control Study. J Clin Microbiol. 2015;53(6):1898-907. doi:10.1128/jcm.00368-15.

20. Jung A, Kleinau I, Schönian G, Bauernfeind A, Chen C, Griese M, et al. Sequential genotyping of Pseudomonas aeruginosa from upper and 
lower airways of cystic fibrosis patients. Eur Respir J. 2002;20(6):1457-63. http://dx.doi.org/10.1183/09031936.02.00268002.

21. Rosenfeld M, Emerson J, Accurso F, Armstrong D, Castile R, Grimwood K, et al. Diagnostic accuracy of oropharyngeal cultures in infants and young children with cystic fibrosis. Pediatr Pulmonol. 1999;28(5):321-8. http:// onlinelibrary.wiley.com/doi/10.1002/\%28SICI\%291099-0496\%28199911\% 2928:5\%3C321::AID-PPUL3\%3E3.0.CO;2-V/abstract.

22. Clinical and Laboratory Standards Institute. Performance Standards for Antimicrobial Susceptibility Testing; Twenty-Second Informational Supplement. CLSI. 2012. http://antimicrobianos.com.ar/ATB/wp-content/ uploads/2012/11/M100S22E.pdf. Accessed 28th October 20142014.

23. European Committeeon Antimicrobial Susceptibility Testing. EUCAST guidleines for detection of resistance mechanisms and specific resistances of clinical and/or epidemiological importance. EUCAST. 2013. http://www.eucast.org/fileadmin/src/media/PDFs/EUCAST_files/Resistance_ mechanisms/EUCAST_detection_of_resistance_mechanisms_v1.0_ 20131211.pdf. Accessed 28th October 20142014

24. Thomassen MJ, Demko CA, Boxerbaum B, Stern RC, Kuchenbrod PJ. Multiple of isolates of Pseudomonas aeruginosa with differing antimicrobial susceptibility patterns from patients with cystic fibrosis. J Infect Dis. 1979;140(6):873-80.

25. Bjarnsholt T, Jensen PO, Jakobsen TH, Phipps R, Nielsen AK, Rybtke MT, et al. Quorum sensing and virulence of Pseudomonas aeruginosa during lung infection of cystic fibrosis patients. PLoS One. 2010;5(4):e10115. doi:10.1371/journal.pone.0010115

26. Costerton JW, Irvin RT, Cheng KJ. The Bacterial Glycocalyx in Nature and Disease. Annu Rev Microbiol. 1981;35(1):299-324. http://dx.doi.org/10.1146/ annurev.mi.35.100181.001503.

27. Drenkard E, Ausubel FM. Pseudomonas biofilm formation and antibiotic resistance are linked to phenotypic variation. Nature. 2002;416(6882):740-3. http://dx.doi.org/10.1038/416740a.

28. Eber E, Zach MS. Pseudomonas aeruginosa infection in cystic fibrosis: prevent, eradicate or both? Thorax. 2010;65(10):849-51. http://dx.doi.org/10.1136/thx.2010.138891.

29. Ołdak E, Trafny EA. Secretion of Proteases by Pseudomonas aeruginosa Biofilms Exposed to Ciprofloxacin. Antimicrob Agents Chemother. 2005;49(8):3281-8. http://dx.doi.org/10.1128/aac.49.8.3281-3288.2005.

30. Bullen JJ. The significance of iron in infection. Rev Infect Dis. 1981;3(6):1127-38. http://dx.doi.org/10.1093/clinids/3.6.1127.

31. Cox CD, Adams P. Siderophore activity of pyoverdin for Pseudomonas aeruginosa. Infect Immun. 1985;48(1):130-8.

32. Valerius NH, Koch C, Hoiby N. Prevention of chronic Pseudomonas aeruginosa colonisation in cystic fibrosis by early treatment. Lancet. 1991;338(8769):725-6.

33. Frederiksen B, Koch C, Høiby N. Antibiotic treatment of initial colonization with Pseudomonas aeruginosa postpones chronic infection and prevents deterioration of pulmonary function in cystic fibrosis. Pediatr Pulmonol. 1997;23(5):330-5. http://dx.doi.org/10.1002/(SICI)1099-0496(199705) 23:5<330::AID-PPUL4>3.0.CO;2-O.

34. Berlana D, Llop JM, Manresa F, Jodar R. Outpatient treatment of Pseudomonas aeruginosa bronchial colonization with long-term inhaled colistin, tobramycin, or both in adults without cystic fibrosis. Pharmacotherapy. 2011;31(2):146-57. doi:10.1592/phco.31.2.146.

35. Herrmann G, Yang L, Wu H, Song Z, Wang H, Hoiby N, et al. Colistintobramycin combinations are superior to monotherapy concerning the killing of biofilm Pseudomonas aeruginosa. J Infect Dis. 2010;202(10):1585-92. doi:10.1086/656788

36. Mainz JG, Schadlich K, Schien C, Michl R, Schelhorn-Neise P, Koitschev A, et al. Sinonasal inhalation of tobramycin vibrating aerosol in cystic fibrosis patients with upper airway Pseudomonas aeruginosa colonization: results of a randomized, double-blind, placebo-controlled pilot study. Drug Des Devel Ther. 2014;8:209-17. http://dx.doi.org/10.2147/dddt.s54064.

37. Moller W, Schuschnig U, Celik G, Munzing W, Bartenstein P, Haussinger K, et al. Topical drug delivery in chronic rhinosinusitis patients before and after sinus surgery using pulsating aerosols. PLoS One. 2013;8(9):e74991. doi:10.1371/journal.pone.0074991.

38. Di Cicco M, Alicandro G, Claut L, Cariani L, Luca N, Defilippi G, et al. Efficacy and tolerability of a new nasal spray formulation containing hyaluronate and tobramycin in cystic fibrosis patients with bacterial rhinosinusitis. J Cyst Fibros. 2014;13(4):455-60. doi:10.1016/j.jcf.2014.02.006.

\section{Submit your next manuscript to BioMed Central and take full advantage of:}

- Convenient online submission

- Thorough peer review

- No space constraints or color figure charges

- Immediate publication on acceptance

- Inclusion in PubMed, CAS, Scopus and Google Scholar

- Research which is freely available for redistribution

Submit your manuscript at www.biomedcentral.com/submit 